\title{
PERAN LEMBAGA KEUANGAN MIKRO PERTANIAN BAGI KETAHANAN PANGAN PETANI INDONESIA
}

\author{
${ }^{1}$ Hasanawi Masturi, ${ }^{2}$ Asyrafinafilah Hasanawi, ${ }^{3}$ Neti Kesumawati \\ ${ }^{1}$ Dosen Program Studi Agribisnis Fakultas Pertanian dan Peternakan \\ Universitas Muhammadiyah Bengkulu, Bengkulu, Indonesia. \\ ${ }^{2}$ Program Studi Perencanaan Wilayah dan Kota Sekolah Arsitektur, Perencanaan, \\ dan Pengembangan Kebijakan Institut Teknologi Bandung, Bandung, Indonesia. \\ ${ }^{1}$ Dosen Program Studi Agroteknologi Fakultas Pertanian \\ Universitas Muhammadiyah Bengkulu, Bengkulu, Indonesia. \\ Email:hasanawimasturi@gmail.com
}

\begin{abstract}
ABSTRAK
Kemiskinan dan kelaparan yang ekstrim didominasi di kawasan perdesaan, dengan proporsi keluarga petani yang sangat signifikan termasuk dalam masyarakat tidak mampu (miskin) dan mengalami kelaparan. Dengan demikian, pemberantasan kemiskinan dan kelaparan secara integral terkait dengan peningkatan produksi pangan, produktivitas pertanian dan pendapatan perdesaan. Selain itu, kondisi iklim yang tidak menentu secara langsung mempengaruhi keberlangsungan pertanian di Indonesia. Indonesia harus mampu menyediakan pangan yang cukup bagi seluruh rakyat dan akses pangan dengan harga terjangkau dengan perubahan yang berisiko tinggi. Berkaitan dengan hal tersebut, pengetahuan mengenai klimatologi penting dilakukan untuk mengantisipasi seperti perubahan iklim. Saat beradaptasi dengan perubahan iklim, kegiatan pertanian dibarengi dengan kegiatan perlindungan dan penguangan risiko hingga level yang paling rendah. Sehingga muncul asuransi usahatani yang bertujuan untuk melindungi pertanian, berbagi risiko, dan memihak petani. Asuransi usahatani, khususnya, berlaku untuk berbagi risiko gagal panen yang disebabkan oleh banjir, kekeringan, serta serangan hama dan penyakit. Penelitian ini menggunakan analisis pada data sekunder tentang ekonomi dan sistem keuangan Indonesia dan informasi yang dikumpulkan dalam wawancara dengan individuindividu kunci (keypersons) di Kementerian Pertanian, Jakarta. Untuk memperjelas data tersebut, dipilih satuKabupaten di provinsi Jawa Barat, Kabupaten Cirebon, dan dua Kabupaten di provinsi Jawa Tengah, Kabupaten Boyolali dan Kabupaten Semarang. Ketiga wilayah tersebut dipilih karena memiliki perkembangan sistem keuangan terutama pertanian daerah yang dinamis, dukungan pemerintah untuk memberikan subsidi pertanianyang aktif. Namun, dikarenakan tidak adanya bank pertanian di Indonesia, lembaga keuangan mikro eksisting diharuskan menyediakan dana yang cukup untuk menutupi biaya produksi. Untuk tindak lanjut jangka pendek, Program Pengembangan Agribisnis Pedesaan (PUAP) saat ini diharapkan dapat membantu petani melalui lembaga keuangan mikro dalam mendanai kegiatan pertanian. Peran keuangan mikro merupakan bagian dari strategi ketahanan pangan dan sangat penting untuk membantu petani dalam meminimalisir efek risiko gagal panen. Praktik pertanian berkelanjutan dan sistem pangan, termasuk produksi dan konsumsi, sebaiknya dilaksanakan dalam perspektif yang holistik dan terintegrasi.
\end{abstract}

Kata kunci : asuransi pertanian, perlindungan pertanian, risiko gagal panen. 


\section{PENDAHULUAN}

\section{Latar Belakang}

Perubahan iklim saat ini dikenal sebagai masalah dunia. Ini adalah salah satu faktor eksternal yang sulit diprediksi dan berdampak serius. Peningkatan konsentrasi $\mathrm{CO}_{2}$ telah menghasilkan gas rumah kaca yang menyebabkan pemanasan global. Dampak negatif akan sangat parah terjadi di negara berkembang karena kerentanan dalam banyak aspek.

Pertanian merupakan sektor ekonomi yang mengalami dampak negatif dari perubahan iklim. Kondisi banjir dan kekeringan yang tidak terduga merupakan faktor utama penyebab gagal panen. Kerusakan infrastruktur, seperti sarana irigasi dan jalur pertanian, merupakan contoh dampak langsung dari ancaman global tersebut. Dampak negatif perubahan iklim yang teridentifikasi adalah: (a) perubahan kalender/masa tanam, (b) terjadinya serangan hama dan wabah penyakit, (c) masalah penanganan pasca panen, akibat intensitas curah hujan yang tinggi, dan (d) gagal panen.
Demikian pula, pasokan pangan tetap bergantung pada pertanian konvensional yang sangat ditentukan dengan iklim. Iklim berada di luar kendali manusia dan oleh karena itu petani harus menyesuaikan diri dengan perubahan iklim. Sejauh ini,satu-satunya cara untuk mengurangi dampak negatif ketidakpastian yang disebabkan oleh perubahan iklim adalah penyesuaian mekanisme petani atau manajemen risiko. Mekanisme petani melakukan penyebaran risiko atau manajemen kerugian sangat mahal di daerah berisiko tinggi seperti daerah kering, semi-kering dan tropis (Binswanger, 1980). Para petani di daerah ini telah melakukan disinvestasi (menjual ternak atau aset lainnya) untuk menutupi biaya produksi, membayar hutang dan melindungi kepemilikan tanah (Walker dan Jodha, 1986).

Padi merupakan tanaman penting yang menempati sekitar 60 persen dari total lahan subur $(20,5$ juta hektar) di Indonesia. Sejak beras menjadi makanan pokok masyarakat Indonesia, pertumbuhan produksinya sangat penting untuk mengurangi 
ketergantungan pada impor. Artinya, menghemat devisa dan meningkatkan akses masyarakat ke pasar beras. Ketersediaan beras dengan harga yang wajar juga membantu mengurangi stabilitas politik dan ekonomi dalam negeri. Beras adalah ketahanan pangan, oleh karena itu pemerintah harus terus mendorong pencapaian swasembada beras. Meskipun menjadi negara penghasil beras terbesar ketiga di dunia, Indonesia tetap menjadi negara pengimpor beras. Ini berlangsung hingga tahun 2004 dengan keputusan yang tidak teratur yang mengizinkan beberapa impor beras untuk menjaga stok nasional pada tingkat yang aman. Setelah peningkatan produksi beras dalam negeri yang signifikan, impor beras diabaikan sejak tahun 2008.

Petani, pejabat pemerintah, dan stakeholders lainnya membawa perspektif baru tentang bagaimana merespon perubahan iklim global saat ini. Dengan uraian tersebut di atas, maka penelitian ini merupakan upaya untuk membahas adaptasi petani terhadap perubahan iklim dalam kaitannya dengan peran lembaga keuangan mikro dalam mendukung produksi beras di Indonesia.

\section{TINJAUAN LITERATUR}

\section{Pencapaian Produksi dan Risiko Pertanian}

Produktivitas (hasil per hektar) padidi Indonesia terus meningkat selama empat dekade terakhir. Meningkat dari rata-rata 2,65 ton per hektar pada 1970-an menjadi 3,86 ton pada 1980 -an, 4,34 ton pada 1990-an dan selanjutnya menjadi 4,61 ton selama 2000 hingga 2008. Pada 2018, rata-rata produksi padi nasional mencapai 5,7 ton per hektar.

Risiko menunjukkan kemungkinan terjadinya suatu peristiwa atau kondisi, yang mungkin memiliki konsekuensi merugikan pada tahap mana pun dalam jalur rantai produksi. Risiko ini berdampak buruk pada keputusan petani saat ini maupun di masa depan dan sangat mengganggu produksi dan pendapatan pertanian, ketika risiko tersebut melewati batas penyerapan dari mekanisme penanganan penyesuaian diri. Risiko produksi dan harga merupakan risiko 
utama dalam pertanian, termasuk pertanian padi. Sumber utama risiko harga adalah ketidakseimbangan permintaan dan penawaran, ketidaksempurnaan pasar, kerugian pasca panen, dan kurangnya produksi atau sistem pendukung stabilisasi pendapatan pertanian.

Risiko terkait dengan proses produksi beras serta penanganan beras hingga mencapai konsumen akhir. Jelas, risiko dihadapi oleh produsen/petani beras serta pemangku kepentingan lainnya yang menjalankan fungsi produksi dan pasokan input, penyaluran kredit, pengolahan dan pemasaran beras. Namun, kelompok yang paling rentan terhadap risiko tersebut adalah petani padi, terutama mereka yang bertani dalam sistem pertanian skala kecil. Strategi manajemen risiko bagi petani padi skala kecil harus berbeda dengan petani lain. Selama beberapa generasi, orang telah peduli dan telah mengembangkan cara dan strategi untuk mengurangi risiko dan mengurangi ketidakpastian. Ini termasuk diversifikasi, pertanian campuran, penanaman campuran, tumpangsari, dan rotasi tanaman. Para petani di Indonesia juga telah melakukan diversifikasi untuk mencegah kegagalan panen yang timbul dari pertanaman tunggal (Hadi et al., 2000; Susilowati dkk., 2002; Sumaryanto, 2006; Saliem dan Supriyati, 2006). Meskipun keutamaan mekanisme manajemen risiko tradisional diakui secara luas, mekanisme tersebut memiliki keterbatasan.

Kegagalan panen akibat banjir, kekeringan, dan serangan hama dan penyakit merupakan hal yang biasa terjadi di Indonesia. Frekuensi dan intensitas risiko semacam itu tidak sama di tempat yang berbeda tetapi pengaruhnya terakumulasi dalam jumlah besar ketika seluruh negara dipertimbangkan. Hadi dkk. (2000) memperkirakan bahwa selama tahun 1989-2008, besarnya kegagalan panen padi akibat ketiga jenis risiko tersebut di atas adalah masingmasing 0,21 persen, 0,50 persen, dan 0,06 persen luas tanam. Data terkini menunjukkan bahwa luas areal padi yang terkena banjir, kekeringan, dan hama penyakit masing-masing adalah 333 ribu, 319 ribu, dan 428 ribu hektar dengan masing-masing sebesar 997 ribu, 984 ribu, dan 352 
ribu ton (2018). Total kerugian produksi akibat banjir, kekeringan, serta serangan hama dan penyakit adalah 2,33 juta ton, atau 4,31 persen dari total produksi tahun 2018. Bagi sebagian besar petani padi yang menggarap lahan kecil (kurang dari 0,3 ha di Jawa/ Bali), kerugian tersebut sangat signifikan. Kerugian tak terduga ini menjadi masalah bagi rumah tangga petani. Hama serangga dan tikus merupakan hama dan penyakit utama yang biasa dihadapi petani di semua sentra penghasil padi di tanah air.

Ketahanan pangan telah lama menjadi prioritas rencana pembangunan nasional Indonesia. Upaya peningkatan produksi pangan diarahkan melalui inovasi teknologi serta implementasi program perbaikan pengelolaan usahatani. Namun, belakangan ini, pemerintah Indonesia menghadapi tantangan yang tidak terduga di sektor tanaman pangan dalam negeri akibat kekurangan pasokan yang menyebabkan tingginya harga beberapa bahan makanan pokok. Kekurangan pasokan terjadi karena fluktuasi produksi tanaman pangan utama (beras, jagung, dan kedelai).
Ketergantungan yang tinggi pada impor menyebabkan ketidakstabilan ekonomi di seluruh negeri. Sementara itu, permintaan akan tanaman semacam itu terus meningkat di dalam negeri karena peningkatan populasi. Oleh karena itu, meningkatnya frekuensi gagal panen dan kehilangan hasil memerlukan respon kebijakan yang mendesak sebagai bagian dari program pembangunan pertanian dan ketahanan pangan. Dalam konteks ini, asuransi tanaman dapat menjadi respons kebijakan strategis terhadap skenario produksi pangan saat ini. Ini adalah salah satu instrumen keuangan untuk mentransfer risiko produksi petani, terkait dengan pertanian, kepada pihak ketiga (perusahaan swasta atau lembaga pemerintah) melalui pembayaran premi dalam jumlah tertentu. Asuransi pertanian sangat penting untuk membantu mencegah petani kecil kehilangan panen dan untuk memastikan bahwa mereka memiliki modal kerja minimum untuk musim tanam berikutnya.

$$
\text { Mengingat masalah }
$$
ketahanan pangan Indonesia saat ini, peran lembaga keuangan mikro 
untuk mendukung asuransi pertanian padi menjadi sangat penting. Risiko iklim beradaptasi dapat dibagi dengan pihak ketiga (perusahaan asuransi) untuk melindungi petani sejalan dengan tujuan pembangunan.
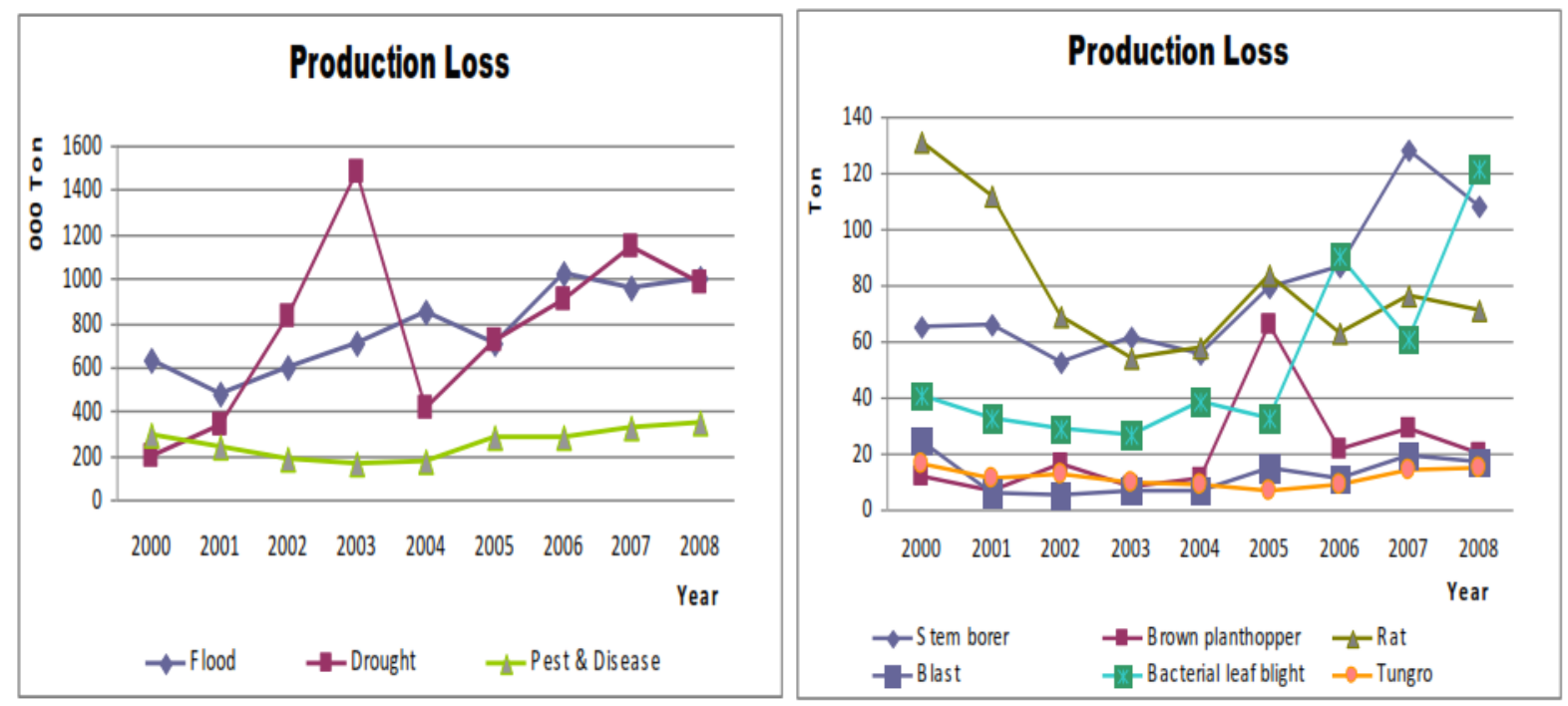

Gambar 1. Grafik Production Loss Akibat Banjir, Kekeringan dan Hama dan Penyakit Pertanian, 2000-2008 (Sumber: Pasaribu et al., 2009)

\section{METODE PENELITIAN}

Analisis ini didasarkan pada data sekunder tentang ekonomi dan sistem keuangan Indonesia dan informasi yang dikumpulkan dalam wawancara dengan individu-individu kunci (Keyperson) di Kementerian Pertanian, Jakarta. Untuk memperjelas data tersebut, dipilih tiga wilayah studi yakni, Kabupaten Cirebon di Jawa Barat dan Kabupaten Boyolali, dan Kabupaten Semarang di Jawa Tengah. Meskipun perekonomian wilayah studi sangat mirip, lembaga keuangan mereka telah berkembang dengan sangat berbeda dari waktu ke waktu. Skema asuransi skala mikro dalam bentuk pilot projecttelah disiapkan sepenuhnya untuk memastikan kelanjutan skema di wilayah yang lebih luas. Dalam konteks ini, langkah yang lebih baru diambil oleh pemerintah adalah pengenalan proyek percontohan oleh Kementerian Pertanian. Proyek serupa lainnya adalah program allriskatau Program Pengembangan Agribisnis Pedesaan (PUAP) (gagal panen akibat ledakan hama dan penyakit) untuk input usahatani di Kabupaten Semarang Provinsi Jawa 
Tengah mencakup 100 hektar sawah dengan 600 peserta/ penerima manfaat.

\section{HASIL DAN PEMBAHASAN}

\section{Peran Lembaga Keuangan Miro}

\section{Pertanian}

\begin{tabular}{lr}
\multicolumn{2}{c}{ Kelembagaan pendukung } \\
sangat penting untuk menuntun \\
keberhasilan
\end{tabular} melakukan adaptasi dan antisipasi terhadap risiko iklim dan kegagalan panen. Kelembagaan petani, seperti kelompok tani, memungkinkan petani bekerja lebih efisien dalam pembelian input, pengendalian hama, penanganan pasca panen, menghimpun dan memasarkan produk mereka bersama-sama. Lembaga non-petani, seperti lembaga keuangan mikro, penyuluhan, dan lain-lain, memegang peranan penting dalam keberhasilan petani dalam bertani. Begitu pula dengan institusi pemerintah yang berurusan dengan kebijakan pendukung (Pasaribu et al., 2009).

\section{Asuransi Pertanian untuk Pembagian Resiko}

Hampir 38\% rumah tangga pedesaan bermatapencaharian sebagai petani padi. Padi atau beras juga merupakan komponen penting makanan sehari-hari masyarakat Indonesia. Padi atau beras memasok $50 \%$ dari kebutuhan energi rata-rata orang Indonesia. Menyadari pentingnya beras dalam ketahanan pangan makro dan rumah tangga dengan memenuhi kebutuhan energi masyarakat dan sebagai sumber mata pencaharian utama petani subsisten skala kecil, kebijakan dalam negeri pemerintah Indonesia diarahkan untuk mencapai swasembada beras. Namun, meskipun menjadi negara penghasil beras terbesar ketiga di dunia, Indonesia tetap menjadi importir beras.

Ada kemungkinan besar untuk meningkatkan hasil padi lebih lanjut, karena sekitar $80 \%$ padi ditanam dengan sistem irigasi. Peningkatan hasil padi penting untuk meningkatkan ketahanan pangan nasional dan rumah tangga serta meningkatkan pendapatan petani padi subsisten skala kecil. Pengalaman di Indonesia dan negara berkembang lain yang serupa menunjukkan bahwa lingkungan 
pendukung yang diperlukan bagi petani untuk meningkatkan produktivitas beras terdiri dari evolusi dan peningkatan teknologi peningkat hasil yang sesuai untuk lokasi tertentu ke petani padi; menciptakan sistem yang efisien untuk menyediakan input modern (bibit unggul, pupuk, praktik agronomi, bahan kimia pelindung tanaman, dll.) untuk petani pada waktu dan tempat yang tepat serta harga yang wajar; dan jaminan pasar yang terjamin untuk surplus beras yang muncul bersama petani setelah penerapan teknologi baru. Hal ini ini membutuhkan investasi baik dari pemerintah maupun petani. Antusiasme petani untuk berinvestasi pada teknologi baru bergantung pada risiko yang dirasakan oleh mereka dalam melakukan investasi tersebut. Risiko yang dihadapi petani padi di Indonesia hingga saat ini masih bersifat alami dan ada pula yang buatan manusia. Kegagalan panen dan hilangnya produksi akibat kekeringan, banjir dan hama dan penyakit sering terjadi di beberapa daerah di Indonesia. Menurut Nurmanaf dkk. (2007), pertanian padi layak untuk dicakup oleh asuransi pertanian.

Tujuan dari kebijakan asuransi tanaman padi di Indonesia harus dipertimbangkan dengan ketentuan sebagai berikut: (a) Untuk mendorong petani untuk meningkatkan produksi dengan mengurangi risiko yang terkait dengan biaya yang lebih tinggi terkait dengan penggunaan teknologi modern baru yang lebih baik; (b) Memberikan perlindungan kepada petani padi dari kerugian panen yang disebabkan oleh faktor alam sehingga mampu memenuhi kebutuhan pokok, termasuk pangan untuk keluarga; (c) Untuk memberikan stabilitas keuangan dan kepercayaan di sektor pertanian, dan dengan demikian mengurangi migrasi petani atau pekerja ke pusat kota; (d) Untuk memastikan pemulihan pinjaman pemerintah atau lembaga pemberi pinjaman lainnya pada saat gagal panen; dan (e) Untuk memfasilitasi pemerintah dalam menganggarkan bantuan kepada petani sebagai bagian dari program tahunan yang berkelanjutan daripada dihadapkan pada program darurat ad hoc, yang seringkali direncanakan 
dan dibiayai dengan terburu-buru, yang sulit untuk dijalankan dan rentan terhadap ketidakadilan dan tekanan lokal.

\section{KESIMPULAN}

Berdasarkan penelitian ini dapat disimpulkan bahwa alternatif kebijakan untuk meningkatkan kapasitas petani dalam beradaptasi dan mengantisipasi perubahan iklim harus mempertimbangkan:

(a) pengembangan praktek tanaman pangan dan sekolah lapang iklim;

(b) peningkatan pelayanan penyuluhan serta pembangunan dan renovasi infrastruktur perdesaan;

(c) pengembangan varietas yang toleran terhadap cekaman biotik, dan

(d) peningkatan akses petani terhadap informasi iklim dan pasar, serta intervensi pemerintah dalam pemasaran hasil pertanian.

Sharing pengetahuan mengenai klimatologi dan iklim sangat penting dan berguna bagi penyuluh dan kelompok tani. Peningkatan arus informasi kondisi iklim dan cuaca,seperti dari Badan Meteorologi, Klimatologi, dan Geofisika (BMKG) ke Dinas Pertanian Provinsi dan Kabupaten hingga ke petani sangat penting dalam menanggulangi dampak perubahan iklim. Pengetahuan ilmiah bersama dengan kearifan lokal yang dikembangkan daerah harus secara signifikan memperkaya pengalaman petani untuk beradaptasi dengan perubahan iklim.

Kondisi risiko usahatani sangat signifikan untuk melindungi kepentingan petani dan, untuk tujuan yang lebih luas, untuk menjaga produksi dan produktivitas beras. Untuk itu, skema asuransi menjadi penting dan peran lembaga keuangan mikro sangat strategis untuk mendukung skema tersebut. Mengingat rendahnya kemampuan finansial para petani skala kecil, pada tahap awal skema asuransi usahatani, intervensi pemerintah menjadi sangat vital. Pemerintah dihimbau untuk berinisiatif dalam memperkenalkan, mengadvokasi dan mensosialisasikan skema tersebut hingga tahap penerapan dan implementasi. Pada tahap awal ini, khususnya dalam 
melaksanakan proyek percontohan di beberapa lokasi, pemerintah harus memberikan dukungan dana untuk pembayaran premi dan biaya operasional lapangan.

Pada tahap pelaksanaan, biaya asuransi akan dibayarkan secara bertahap oleh petani dan dapat dimasukkan ke dalam biaya produksi. Lembaga keuangan mikro di bawah Program Pengembangan Agribisnis Pedesaan (PUAP) saat ini yang tersebar di seluruh negeri akan memenuhi syarat untuk membiayai skema asuransi bersama dengan biaya produksi lainnya, terutama bagi petani yang tidak bankable. Komitmen yang konsisten untuk adaptasi pemangku kepentingan terhadap risiko iklim melalui asuransi pertanian akan meningkatkan produksi tanaman pertanian dan meningkatkan pendapatan petani.

\section{DAFTAR PUSTAKA}

Binswanger, H. P. (1980). “Attitudes towards Risk: Experimental Measurement in Rural India", American Journal of Agricultural Economics 62 (3): 174-82.
Boer, R. (2009). Sekolah Lapangan Iklim: Antisipasi Risiko Perubahan Iklim. Majalah Salam, No. 26, January 2009. pp. 8-10. www.salam.leisa.info.

Hadi, P. U., C. Saleh, A. S. Bagyo, R. Hendayana, Y. Marisa, and I. Sadikin. (2000). Studi Kebutuhan Asuransi Pertanian Pada Pertanian Rakyat (Study on Agricultural Insurance Requirements for Smallholder Farms). Research Report, Pusat Penelitian Sosial Ekonomi Pertanian, Bogor.

Nurmanaf, A. R. Sumaryanto, S.Wahyuni, E.Ariningsih, andY.Supriyatna. (2007). Analisis Kelayakan dan Perspektif Pengembangan Asuransi Pertanian pada Usahatani Padi dan Ternak Potong (Feasibility Analysis and Development Perspective of Agricultural Insurance for Rice Farm and Beef Production). Research Report, Pusat Analisis Sosial Ekonomi dan Kebijakan Pertanian, Bogor. 
Pasaribu, S. M., H. P. Saliem, and E.

Ariningsih.

(2009).

Agricultural Insurance for Rice

Farming in Indonesia.

Research Report. Pro-Poor

Policy Formulation, Dialogue,

andImplementationatCountryL

evel:Indonesia(CGP/RAS/214/I

FA). ICASEPS, Bogor and

FAO-RAP, Bangkok.

Pasaribu, S.M., H. Mayrowani, D.K. Swastika, M. Iqbal, A.K. Zakaria, T. Nurasa, V. Darwis, and J. Hestina. (2008). Peningkatan Kapasitas Adaptasi Petani di Daerah

Marginal TerhadapPerubahan

Iklim.Research

Report,PusatAnalisisSosial

Ekonomi dan Kebijakan

Pertanian, Bogor.

Pusat

Pembiayaan

Pertanian.(2009).Asuransi

Pertanian:KasusPilotProjectAs

uransi Tanaman Padi dan

Ternak (Agricultural

Insurance: The Case of Pilot

Project of Rice Farm and

Livestock Insurance)", Paper

presented at a seminar held by

IFC on 18 February 2009 in

Jakarta, Pusat Pembiayaan
Pertanian, Sekretariat Jenderal

Departemen Pertanian, Jakarta.

Saliem, H. P. and Supriyati. (2006).

Diversifikasi Usahatani dan Tingkat Pendapatan Petani di Lahan Sawah (Farm Diversification and Farmer's Income Level in Wetland Areas). In AGRIDIV In-

Country Seminar: Poverty Alleviation through

Development of Secondary Crops, Bogor, 23 March.

Sumaryanto. (2006). Faktor-Faktor yang Mempengaruhi Keputusan Petani Menerapkan Pola Tanam Diversifikasi: Kasus di Wilayah Pesawahan Irigasi Teknis DAS Brantas (Factors Affecting Farmers' Decision to Apply Diversification of Crop Pattern). In AGRIDIV InCountry Seminar: Poverty Alleviation through Development of Secondary Crops, Bogor, 23 March 2008.

Susilowati, S. H., Supadi, and C. Saleh. (2002). "Diversifikasi Sumber Pendapatan Rumah Tangga di Pedesaan Jawa Barat 
(Diversification of Farmers' Income Sources in Rural Area of West Java)". Jurnal Agro Ekonomi 20 (1): 85-109.

Walker, A. S. and N. S. Jodha. (1986). How Small Farm Households Adopt to Risk? In Hazell et al. (Eds): Crop Insurance for Agricultural Development. John Hopkins University Press. Baltimore and London. 